\title{
Determination of High lodine Levels by ICP-OES after Separation from Excess Phosphate by Co-precipitation
}

\author{
M. Sager \\ Austrian Agency for Health and Food Safety (AGES), Institute for Food Safety, Vienna, Austria
}

\begin{abstract}
For determination of iodine, dissolution or oxidation of an organic matrix by acid K-chlorate in dilute nitric acid to obtain non-volatile iodate immediately, is a method of choice. Optical emission spectroscopy is usually sensitive enough to control iodized table salt. Spectral interference by $\mathrm{P}$ upon the most sensitive I-emission line, e.g. in mineral feeds and marine algae, was overcome by co-precipitation of $\mathrm{P}$ with $\mathrm{Al}$ - or Fe hydroxide, leaving iodate (and also borate) in solution. After addition of $\mathrm{Al}$ or $\mathrm{Fe}$ nitrate or sulfate, ammonia was added to reach $\mathrm{pH}$ 8.8, and the resulting precipitate separated by cetrifugation and decantation. Al-hydroxide was more efficient, and its precipitation was facilitated by adding 10-30 mg of a natural clay to $5 \mathrm{~mL}$ sample. Correct results with materials from former ring tests were obtained down to $15 \mathrm{mg} / \mathrm{kg}$ by an ICP 20 years of age.
\end{abstract}

Highlights: This method enables to use optical emission ICP for determination of high levels of iodine after a simple separation of phosphate from oxidizing acid digests, thus avoiding catalytic or spectrophotometric methods, or high blanks in an ICP-MS utilized for ambient iodine levels.

Key words: Iodine, marine algae, feed premixes, ICP-OES.

\section{Introduction}

\subsection{Iodine-Occurrence and Nutrition}

Iodine levels in food and feed samples should attract attention, because the beneficial physiological range between essentiality and toxicity for the human organism lies between rather narrow limits. It means crust occurrence has been reported at $0.80 \mathrm{mg} / \mathrm{kg}$, in the upper crust at $1.4 \mathrm{mg} / \mathrm{kg}$, and in the lower crust at $0.14 \mathrm{mg} / \mathrm{kg}$ [1]. It gets enriched in the biosphere, and thus among geological materials, in coals $(<0.3-2.2$ $\mathrm{mg} / \mathrm{kg}$ ) and shales (2-6 mg/kg).

Iodine may occur in gaseous forms (e.g. in the atmosphere, as $\mathrm{HI}, \mathrm{IO}, \mathrm{I}_{2}, \mathrm{CH}_{3} \mathrm{I}$ ) [2], in solutions (as iodide, iodate, or organo-iodine-compounds) [3], but rarely in solids; e.g. AgI and $\mathrm{HgI}_{2}$ are hardly soluble. Because nearly all compounds are water-soluble, sea-water acts as a sink for iodine, mainly as $\mathrm{ICl}_{3}{ }^{-}$, or

Corresponding author: Manfred Sager, Doz. Dr., research field: inorganic and trace element analysis. iodate. Iodide is kinetically meta-stable in oxygenated waters. Marine bacteria are not capable to oxidize iodide up to iodates, but form either molecular iodine or organic iodine compounds. In case of eutrophication or pronounced sedimentary influence, biogeochemical processes and organic I-compounds may be substantial. Organo-iodine compounds may be formed by fixation of iodide on humics, as well as in the course of potable water disinfection, via the formation of HIO, which readily reacts with aromatic compounds $[4,5]$.

In the sea, phytoplanktons produce $\mathrm{CH}_{2} \mathrm{I}_{2}, \mathrm{CH}_{2} \mathrm{IBr}$ and probably $\mathrm{I}_{2}$, which are also photolabile in the boundary layer. The resultant gases are transported with clouds, and finally precipitated from the atmosphere [6]. Methyldiiodide from algal production gets photolytically cleaved to iodine atoms, which react with atmospheric ozone to yield IO. The global flux of iodine to the atmosphere mediated by macroalgae is estimated at $10-100$ tons per year, mainly at coastal zones, whereas the global flux to the 
atmosphere mediated by phytoplankton is 1,000-10,000 tons per year, taking place all over the ocean. Bacteria are supposed to synthesize methyl iodide, and cause a similar iodine flux from the ocean to the atmosphere at $1,000-10,000$ tons per year [7]. In the atmosphere, iodine is trapped in the clouds and soon gets precipitated with rainfall to the surface.

Thus, soils show considerable enrichment of iodine compared with their parent materials, because they get appreciable inputs from the atmosphere. The iodine status of a soil depends on the supply and the ability to retain it, which is due to $\mathrm{pH}$, organic content, and pedogenic oxides, whereas the impact of clay contents seems to be low $[4,8]$. Due to the marine origin of limestones, however, Austrian soils developed upon limestones contain more iodine than soils upon parent igneous rocks [9].

Therefore, iodine levels can be expected to decrease with the distance to the oceans, to be higher in plains than in mountains, and very low in diluvial sediments which have been eluted by melting glaciers after the end of the ice age. This may lead to iodine deficiencies at locations distant to the sea, and to iodine supplementation of the population via iodinized table salt, or iodinized composite feeds for domestic animals.

In 2000 [10], the recommended daily intake for an adult has been risen from $150 \mu \mathrm{g}$ to $200 \mu \mathrm{g}$, whereas pregnants are supposed to need $230 \mu \mathrm{g}$, and lactating mothers even $260 \mu \mathrm{g}$, to satisfy the needs of the foetus or the baby. About 1/3 of global population suffer from iodine deficiency, in particular inside continents and in mountain areas. In Austria, main sources for iodine in food are milk [11], eggs [12] and table salt (see Table 1), whereas the consumption of marine fish and seafood is not so pronounced, because of some distance to the sea. Factor weights obtained from principal component analysis of non-metal concentrations found in ready-made meals showed relations between iodine and selenium, but not between selenium and sulfur [13].

For estimation of the daily intake by men, possible iodine losses during cooking have to be kept in mind, as well as lowering iodine resorption by thiocyanates and glucosinolates.

Also, excretion of iodine in urine correlates fairly well with $\mathrm{Na}$, but not with $\mathrm{K}$ and $\mathrm{S}$ (unpublished).

Therefore, additional supply in table salt and animal feeds is usual in Europe, which has to be controlled by the authorities. The upper permissible level in composite feeds has been currently set to $4 \mathrm{mg} / \mathrm{kg}$ for horses and donkeys, to $5 \mathrm{mg} / \mathrm{kg}$ for dairy cows and layers, to $20 \mathrm{mg} / \mathrm{kg}$ for fish, and to $10 \mathrm{mg} / \mathrm{kg}$ for other domestic animals [14], but food supplements like special marine algae, or feed components, might contain even much more.

\subsection{Determination by Optical Emission}

For the determination of iodine contents at ambient levels, ICP-MS is currently the method of choice,

Table 1 Iodination of table salt.

\begin{tabular}{ll}
\hline Not iodinized & \\
\hline "Bergkern” & $<0.01 \mathrm{mg} / \mathrm{kg}$ \\
From the sea & $0.29 \mathrm{mg} / \mathrm{kg}$ (Dar es Salaam) \\
\hline Iodinized & $5 \mathrm{mg} / \mathrm{kg}$ \\
\hline Norway & $13 \mathrm{mg} / \mathrm{kg}$ \\
Denmark & $15-20 \mathrm{mg} / \mathrm{kg}$ from NaJ or KJ \\
Austria & $20(1962-1980: 7.5 \mathrm{mg} / \mathrm{kg} ; 1980-1998: 15 \mathrm{mg} / \mathrm{kg})$ \\
Switzerland (since 1998$)$ & $20 \mathrm{mg} / \mathrm{kg}$ \\
Germany & $35 \mathrm{mg} / \mathrm{kg}(1992-2000: 50 \mathrm{mg} / \mathrm{kg})$ \\
China & $76 \mathrm{mg} / \mathrm{kg}$ \\
\hline USA &
\end{tabular}


because ${ }^{127}$ I I has a $100 \%$ abundance, and no other masses appear there. Interferences from nebulization, however, remain the same in both ICP-MS and ICP-OES. Volatile species of iodine $\left(\mathrm{I}_{2}\right.$ or $\left.\mathrm{HI}\right)$ in acidic media enhance the signal to unstable values (author's experience [15]). Therefore, iodine can be determined either as iodate in oxidizing acid solution, or as iodide in reducing alkaline solution, irrespective of the ICP technique used.

Iodine determination by ICP-OES is rather insensitive. The most sensitive line at $178.225 \mathrm{~nm}$ is strongly interfered by an adjacent line of $\mathrm{P}$, and in case of biological samples might yield just a shoulder at the $\mathrm{P}$ line. A (nonlinear) correction of the I-178 line with $10 / 40 / 100 \mathrm{mg} / \mathrm{L} \mathrm{PO}_{4}$ is necessary. The detection limit depends on the actual power of the torch and the salt matrix, but is not much below $\sim 0.1 \mu \mathrm{g} / \mathrm{mL}$, which is not suitable for ambient levels.

Other atomic emission lines of iodine have been found at $184.445 \mathrm{~nm}$ (interfered by Ge), and at 206.163 nm (interfered by Zn, Bi and Cr) [16, 17]. Using a Meinhard concentric nebulizer, lateral view and high forward power, a detections limit of $2 \mu \mathrm{g} / \mathrm{L}$ could be reached at $178.218 \mathrm{~nm}$, but only $30 \mu \mathrm{g} / \mathrm{L}$ at $182.980 \mathrm{~nm}$ [15]. P is known to be a major spectral interferent with the most sensitive line at $178 \mathrm{~nm}$, making the determination of iodine in real samples impossible. Both iodine lines are interfered with by carbon, which can be overcome by suitable background correction [15].

In order to improve the iodine status of domestic animals, particularly in iodine deficient areas, iodides or iodates are added to commercially available feeds, which has to be controlled, e.g. within our lab. For human nutrition, iodinized table salts (Table 2) as well as supplementaion pills are on the market. In case of iodine supplementation pills, food supplements like marine algae, iodinized salt and feed components, iodine levels might be high enough to be determined by ICP-OES, at least as a pre-screening method. Thus, a simple separation of iodine and phosphorus might be useful. Because of high memory effects, samples presumably containing high levels of iodine, should be treated in vessels and instruments different to samples at ambient levels (milk, eggs, fruits; urine and blood), which usually go to the ICP-MS.

In the literature, digestion methods with nitric-perchloric acid or nitric acid-hydrogen peroxide to end up with non volatile iodate had been done obviously successfully [18-20], while other authors reported losses of the analyte $[15,21]$.

As a suitable digestion method, acid oxidation with $\mathrm{KClO}_{3}$ in dilute nitric acid has been the matter of choice, since all iodine gets converted to non-volatile iodate, sulfur to sulfate, and carbon largely to $\mathrm{CO}_{2}$ [22].

\subsection{Separation of Iodate and Phosphate}

Because in biological materials, always much more $\mathrm{P}$ than I has to be expected, a separation seems mandatory. Online separation done by oxidation of iodide containing sample solutions with nitrite in dilute

Table 2 Solubility of pure phosphates: calculated phosphate concentration after dissolution of the respective solid, without further reaction (pKL = solubility product; $\mathbf{p}\left(\mathrm{PO}_{4}\right)$ = negative dekad, logarithm of calculated phosphate concentration) [30].

\begin{tabular}{lll}
\hline & $\mathrm{pKL}$ & $\mathrm{p}\left(\mathrm{PO}_{4}\right)$ \\
\hline $\mathrm{BiPO}_{4}$ & 22.9 & 11.45 \\
$\mathrm{CePO}_{4}$ & $18.5 / 23.0$ & $9.25 / 11.5$ \\
$\mathrm{Th}_{3}\left(\mathrm{PO}_{4}\right)_{4}$ & $57.6 / 78.6$ & $8.2 / 11.2$ \\
$\mathrm{FePO}_{4}$ & 21.9 & 11 \\
$\mathrm{AlPO}_{4}$ & 18.2 & 9.1 \\
$\mathrm{Ba}_{3}\left(\mathrm{PO}_{4}\right)_{2}$ & 28.9 & 5.9 \\
$\mathrm{Ca}_{3}\left(\mathrm{PO}_{4}\right)_{2}$ & 25.0 & 5.1 \\
$\mathrm{Mg}\left(\mathrm{NH}_{4}\right) \mathrm{PO}_{4}$ & 12.6 & $4.2\left(6.3\right.$ in $\left.1 \mathrm{M} \mathrm{NH}_{3}\right)$ \\
\hline
\end{tabular}


sulfuric acid to yield the volatile element may enrich the signal 33-fold [23] and permit the use of ICP-OES at lower iodine levels [17, 20, 24, 25]. In a routine lab like this, however, change of the ICP-configuration might block the equipment too long, and possibly necessitate a re-validation of the routine configuration, the latter which ensures the main source of income.

Though this technique might be rather empirical, co-precipitation has some advantages among possible separation techniques. Many samples can be done simultaneously, no organic solvents are needed, and there is some visual control. Because almost all ortho-phosphates, except the alkali phosphates, are hardly soluble at neutral or alkaline $\mathrm{pH}$, it was reasonable to try to precipitate the phosphates, and leave the soluble iodates in solution. Simple calculations from the solubility products show that the phosphates of $\mathrm{Bi}, \mathrm{Ce}$, Th, $\mathrm{Fe}$, and $\mathrm{Al}$ are the least soluble. For practical reasons, $\mathrm{Fe}$ and $\mathrm{Al}$ were selected. Because additional salts would not be favorable for the ICP-torch, ammonia solution was tried as a source of alkali.

During the digestion of plant and else material, variable amounts of acid are consumed, thus the amount of $\mathrm{NH}_{3}$ to reach the optimum $\mathrm{pH}$ is clearly less than needed for the same amount of fresh reagent. A wheat sample of ambient iodine content, which is far too low to be seen by ICP-OES, was properly digested, spiked, and used as a matrix to optimize co-precipitation of $\mathrm{P}$ with Al- or F-hydroxide. A series of experiments were set up to check, how much $\mathrm{Al}$ or Fe is needed to precipitate all excess $\mathrm{P}$ over I, how much $\mathrm{NH}_{3}$ to reach an optimum $\mathrm{pH}$ to get sufficient precipitate, to avoid reduction of iodate, and to avoid the extinction of the plasma by excess gaseous $\mathrm{NH}_{3}$.

\section{Material and Methods}

Microwave digestion unit: mls 1200 mega MLS GmbH, D-88299 Leutkirch.

Rotors with 6 PTFE vessels of about $25 \mathrm{~mL}$ were used
Time/power program: 2 min $250 \mathrm{~W} / 1 \mathrm{~min}$ 0/8 min $250 \mathrm{~W} / 1 \mathrm{~min} 0 / 6 \mathrm{~min} 450 \mathrm{~W} / 4 \mathrm{~min} 600 \mathrm{~W} / 1 \mathrm{~min} 500$ $\mathrm{W}$ (see also [26, 27])

ICP-OES: Perkin Elmer Optima 3000XL with axial plasma, cross flow nebulizer

A program different to the default values was used: forward power $1,450 \mathrm{~W}(\max =1,500 \mathrm{~W})$

Plasma gas $15 \mathrm{~L} / \mathrm{min} / /$ neb. $0.7 \mathrm{~L} / \mathrm{min} / /$ aux. 0.5 $\mathrm{L} / \mathrm{min}$

Al-solution: $5 \%$ Al-nitrate $=5 \mathrm{~g}$ aluminum nitrate nonahydrate Merck (> 95\%) Nr. 1.01086, in $100 \mathrm{~mL}$ $\mathrm{H}_{2} \mathrm{O}$

Fe-solution: 10,000 mg/L Fe calibrant $=\mathrm{Fe}\left(\mathrm{NO}_{3}\right)_{3}$ in $10 \% \mathrm{HNO}_{3}$, Merck Nr. 170376

One gram sample of plant origin was weighed into a $25 \mathrm{~mL}$ pressure bomb vessel, $8 \mathrm{ml}$ of digestion solution mixture is added, closed and submitted to microwave assisted heating. After cooling, the digest was made up to 20 or $25 \mathrm{~mL}$ with water [22].

Digestion solution mixture $=200 \mathrm{~mL} \mathrm{H}_{2} \mathrm{O}+20 \mathrm{~g}$ $\mathrm{KClO}_{3}+80 \mathrm{~mL} \mathrm{HNO}_{3}$ conc.

Mineral mixtures without the need of intense organic carbon oxidation might be heated in beakers as well.

Four $\mathrm{ml}$ of sample solution was pipetted into a test tube, $0.5 \mathrm{ml}$ of $\mathrm{Al}$ or Fe solution was added to reach at least $400 \mu \mathrm{g} / \mathrm{mL}$ in the final solution, mixed, and sufficient concentrated aqueous ammonia solution to achieve a permanent precipitate and to reach a $\mathrm{pH}$ of about 8.8. This can be checked by test strips. Adding some clay (10-30 mg) as a crystallisation seed proved to be beneficial.

The addition of clay was a seed for crystallisation and an aid in centrifugation, because the precipitates were often colloidal and did not precipitate as much as they should. The clay was termed as a remover of mineral oil from water traded as "Derolin” (Háztartási étolajderitö), and occurs at a quarry in the Northeast of Hungary. No other clay was tested.

After 2-3 hours and addition of water to make up all samples to $5 \mathrm{~mL}$, the tubes were closed with stoppers, 
the samples were centrifuged for 10 minutes at high speed, and the supernanant transferred to another test tube with a pipette, ready for measurement or further dilution.

The ICP-OES multi-element program designed for the analysis of anions reads boron, germanium, silicon, iodine, phosphorus and sulfur simultaneously. Calibration points for B-Ge-I-Si were set at 1-2-3-6 $\mu \mathrm{g} / \mathrm{mL}$, and for P-S were set at 10-20-40 $\mu \mathrm{g} / \mathrm{mL}$.

A winter wheat sample (variety CAPO) grown at the experimental field at Fuchsenbigl (Lower Austria) upon chernozem soil was used for recovery studies of $2 \mu \mathrm{g}$ and $4 \mu \mathrm{g}$ I, added as $\mathrm{KIO}_{3}$.

\section{Results and Discussion}

A minimum amount of about $400 \mu \mathrm{g} / \mathrm{mL} \mathrm{Al}$ or $\mathrm{Fe}$ (sulfate or nitrate) was needed to produce enough precipitate for complete coprecipitation. $\mathrm{pH} 8.8$ must be reached, otherwise the co-precipitation is not complete. This requires about $0.2 \mathrm{~mL} \mathrm{NH}_{3}$ conc. for digests of wheat and algae, but $0.5 \mathrm{~mL} \mathrm{NH}_{3}$ conc. for mineral feeds. Addition of a crystallisation seed (like 10-40 mg “Derolin” clay from Hungary per test tube) was not essential, but beneficial; its effects were equal if done before or after the precipitation. The reaction time should not be too long (overnight), because the remaining chlorate seems to oxidize ammonia forming acid, and thus redissolving the precipitate: $5 \mathrm{NH}_{4}{ }^{+}+$ $3 \mathrm{ClO}_{3}{ }^{-}->3 \mathrm{Cl}^{-}+9 \mathrm{H}_{2} \mathrm{O}+2 \mathrm{H}^{+}$.

Whereas the recovery of iodate and borate in the supernatant was complete, phosphate was completely removed, rendering signal corrections obsolete. Silicate and germanate recovery was variable, whereas sulfate was contained in the added $\mathrm{Al}$ or Fe solutions, and thus higher than original.

The method was successfully applied to test substances from previous ring tests, like spiked green plants, mineral feeds and brown algae. Levels $>15$ $\mathrm{mg} / \mathrm{kg}$ were correctly found (Table 3). Reproducibility using $\mathrm{Al}$ was better than with $\mathrm{Fe}$. Calibrant solutions were prepared at the same levels of $\mathrm{KClO}_{3}-\mathrm{HNO}_{3}$ like the sample solutions. Because the iodine emission intensity depends rather much on the power of the torch (see also [21]), standard addition is supposed to improve the precision.

Whereas clays trend to adsorb cations, they seem to be largely inert versus many anions, which is attributable to anion exclusion from the negative surface charges. Batch tests showed that iodide ions within $10^{-5}-10^{-1} \mathrm{M}$ concentration were negligibly adsorbed onto bentonite (containing 70\% montmorillonite) at various $\mathrm{pH}$ (7-14) and salinity (up to $1 \mathrm{M} \mathrm{NaCl}$ ), which is the expected concentration range for iodate in the digests expected for this work. Starting from iodide solutions, at $\mathrm{pH}>11$ some iodate should also be present due to calculations [27].

In spite of lower expectable solubility of Fe-phosphate than Al-phosphate, sorbed amounts of phosphate increased within the order goethite < boehmite $<$ ferrihydrite < amorphous Al-hydroxide, in presence of $0.01 \mathrm{M} \mathrm{KCl}$ at $\mathrm{pH}$ 6. XANES-technique on moist samples revealed Al-phosphate precipitation in mixed systems, but no evidence of Fe-phosphate formation upon Fe-hydroxide surfaces, which explains that after precipitation of equimolar mixtures of $\mathrm{Fe}$ and $\mathrm{Al}, 70-86 \%$ of the phosphate got associated with $\mathrm{Al}$ [28]. That is why also in this work, co-precipitation with $\mathrm{Al}$ was more effective than with Fe.

Table 3 Recovery and test with real samples.

\begin{tabular}{lllll}
\hline Organization & Matrix & Ringtest $(\mathrm{mg} / \mathrm{kg})$ & Coprec. with Al (mg/kg) & Coprec. with Fe (mg/kg) \\
\hline- & Wheat $+2 \mu \mathrm{g},+4 \mu \mathrm{g} \mathrm{I}$ & - & $101 \pm 12 \%$ & $68 \pm 18 \%$ \\
VDLUFA 150/3 & Brown algae & $726 \pm 121$ & $457 \pm 64$ & $430 \pm 16$ \\
VDLUFA 150/5 & Mineral feed & $15 \pm$ & $21 \pm 10$ & $7 \pm 3$ \\
ALVA-PA14/3 & Mineral feed for dairy cows & $98 \pm 5.4$ & $102 \pm 16$ & $89 \pm 43$ \\
ALVA-PA16/1 & Mineral feed for piglets & $33 \pm 5$ & $37 \pm 12$ & $33 \pm 4$ \\
\hline
\end{tabular}

Remark: the instrument has been in use for 20 years; precision may be improved by use of more recent equipment. 
A mixed hydroxide-phosphate has been known as the mineral wavellite $\left(\mathrm{Al}_{2}\left[(\mathrm{OH})_{3}\left(\mathrm{PO}_{4}\right)\right] \cdot 5 \mathrm{H}_{2} \mathrm{O}\right)$.

Phosphate adsorption upon gibbsite (monoclinic $\alpha$ $\left.\mathrm{Al}(\mathrm{OH})_{3}\right)$ at $\mathrm{pH}=5.5$ was not affected by $\mathrm{Na}, \mathrm{K}, \mathrm{Mg}$ or $\mathrm{HCO}_{3}$ up to $0.02 \mathrm{M}$ solutions, and Ca greatly increased P adsorption between 1-100 $\mu \mathrm{M}$ [29]. This means that there is no apparent obstacle to apply the proposed method to several mineral feed component mixtures.

\section{Conclusions}

After digestion with $\mathrm{KClO}_{3}$ in dilute nitric acid, excess phosphate can be removed from the sample solution by precipitation of aluminum phosphate in ammoniacal solution at $\mathrm{pH}$ of about 9, rendering iodate in solution. This enables to use an optical ICP for determinations of iodine at high levels, at the most sensitive line at $178 \mathrm{~nm}$.

\section{References}

[1] Wedepohl, K. H. 1995. "The Composition of the Continental Crust." Geochimica et Cosmochimica Acta 59 (7): 1217-32.

[2] Zingler, J., and Platt, U. 2005. "Iodine Oxide in the Dead Sea Valley: Evidence for Inorganic Sources of Boundary Layer IO.” Journal Geophysical Research 110: D07307, doi: 10.1029/2004JD004993.

[3] Hou, X., Dahlgaard, H., Rietz, B., Jacobsen, U., Nielsen, S. P., and Aarkrog, A. 1999. "Determination of Chemical Species of Iodine in Seawater by Radiochemical Neutron Activation Analysis Combined with Ion-Exchange Pre-separation.” Analytical Chemistry 71: 2745-50.

[4] Fuge, R. 1990. "The Role of Volatility in the Distribution of Iodine in the Secondary Environment." Applied Geochemistry 5: 357-60.

[5] Gong, T., and Zhang, X. 2013. "Determination of Iodide, Iodate and Organo-Iodine in Waters with a New Total Organic Iodine Measurement Approach.” Water Research 47: 6660-9.

[6] Saiz-Lopez, A., Mahajan, A. S., Salmon, R. A., Bauguiutte, J. B., Jones, A. E., Roscoe, H. K., and Plane, J. M. C. 2007. "Boundary Layer Halogens in Coastal Antarctica.” Science 317: 348-51.

[7] O’Dowd, C. D., Jimenez, J. L., Bahreini, R., Flagan, R. C., Seinfeld, J. H., Hämeri, K., Pirjola, L., Kulmala, M., Jennings, S., and Hoffmann, T. 2002. "Marine Aerosol
Formation from Biogenic Iodine Emissions.” Nature 417 (6): 633-5.

[8] Takata, H., Zheng, J., Tagami, K., Aono, T., Fujita, K., Yamasaki, S., Tsuchiya, N., and Uchida, S. 2013. "Distribution Coefficients (Kd) of Stable Iodine in Estuarine and Coastal Regions, Japan, and Their Relationship to Salinity and Organic Carbon in Sediments." Environmental Monitoring and Assessment 185: 3645-58.

[9] Gerzabek, M. H., Muramatsu, Y., Strebl, F., and Yoshida, S. 1999. "Iodine and Bromine Contents of Some Austrian Soils and Relations to Soil Characteristics.” Journal of Plant Nutrition and Soil Science 162: 415-9.

[10] D-A-CH. 2000. Referenzwerte für die Nährstoffzufuhr. Umschau Braus GmbH Verlagsgesellschaft Frankfurt/Main, 1st ed.

[11] Sager, M., and Hobegger, M. 2013. "Elementgehalte in Rohmilch aus drei Regionen Niederösterreichs Contents of Elements in Raw Milk from Three Regions in Lower Austria Ernährung.” Nutrition 37 (7/8): 277-90.

[12] Sager, M. 2011. "Mengen- und Spurenelemente in österreichischen Hühnereiern. Ernährung.” Nutrition 35 (2): 53-8.

[13] Sager, M. 2010. “Über die Elementzusammensetzung von in Österreich erhältlichen Fertiggerichten und Wurstwaren. Ernährung.” Nutrition 34 (2): 57-64.

[14] Commission Regulation (EC) No. 1459/2005 of 8 September 2005. "Amending the Conditions for Authorisation of a Number of Feed Additives Belonging to the Group of Trace Elements.” Official Journal of the European Union.

[15] Niedobova, E., Machat, J., Kanicky, V., and Otruba, V. 2005. "Determination of Iodine in Enriched Chlorella by ICP-OES in the VUV Region.” Microchimica Acta 150: 103-7.

[16] Buresch, O., Hönle, W., von Schnering, H. G. 1986. "Quantitative Bestimmung von Iod mittels AES-ICP in anorganischer und organischer Matrix.” Fresenius Zeitschrift für Analytische Chemie 325: 607-10.

[17] Nakahara, T., and Mori, T. 1994. "Analyte Volatilization Procedure for the Determination of Low Concentrations of Iodine by Inductively Coupled Plasma Atomic Emission Spectrometry.” Journal of Analytical Atomic Spectrometry 9: 159-65.

[18] Larsen, E. H., Knuthsen, P., and Hansen, M. 1999. "Seasonal and Regional Variations of Iodine in Danish Dairy Products." Journal of Analytical Atomic Spectrometry 14: 41-4.

[19] Julshamn, K., Dahl, L., and Eckhoff, K. 2001. "Determination of Iodine in Seafood by Inductively Coupled Plasma/Mass Spectrometry." Journal of the Association of Official Analytical Chemists International 


\section{Excess Phosphate by Co-precipitation}

84 (6): 1976-83.

[20] Rakoczy, R., Kopec, A., Piatkowska, E., Smolen, S., Skoczylas, L., Lszczynska, T., and Sady, W. 2016. “The Iodine Content in Urine, Faeces and Selected Organs of Rats Fed Lettuce Biofortified with Iodine through Foliar Application.” Biological Trace Element Research 174: 347-55.

[21] Naozuka, J., Mesquita, Silva da Veiga, M. A., Vitoriano, O. P., and de Oliveira, E. 2003. "Determination of Chlorine, Bromine and Iodine in Milk Samples by ICP-OES.” Journal of Analytical Atomic Spectrometry 18: 917-21.

[22] Sager, M. 2011. "Microwave-Assisted Digestion of Organic Materials with $\mathrm{KClO}_{3} / \mathrm{HNO}_{3}$ for the Analysis of Trace Metals and Non-metals.” Analytical Chemistry 10 (2): 101-8.

[23] Dolan, S. P., Sinex, S. A., Capar, S. G., Montaser, A., and Clifford, R. H. 1991. "On-Line Preconcentration and Volatilization of Iodine for Inductively Coupled Plasma Atomic Emission Spectrometry.” Analytical Chemistry 63: 2539-42.

[24] Anderson, K. A., Casey, B., Diaz, E., Markowski, P., and Wright, B. 1996. "Speciation and Determination of Dissolved Iodide and Iodine in Environmental Aqueous Samples by Inductively Coupled Plasma AES.” Journal of the Association of Official Analytical Chemists
International 79 (3): 751-6.

[25] Anderson, K. A., and Markowski, P. 2000. "Speciation of Iodide, Iodine, and Iodate in Environmental Matrices by Inductively Coupled Plasma Atomic Emission Spectrometry Using in Situ Chemical Manipulation.” Journal of the Association of Official Analytical Chemists International 83 (1): 225-30.

[26] Sager, M. 2010. “Analysis of Less Bioactive Elements in Green Plants, Food and Feed Samples (Sc-Y-La-Ce-Rb-Cs-Ti).” Ecological Chemistry and Engineering 17 (3): 289-95.

[27] Lee Jae, O., Cho, W. J., and Choi, H. 2013. "Sorption of Cesium and Iodide Ions onto KENTEX-Bentonite." Environmental Earth Science 70: 2387-98.

[28] Khare, N., Hesterberg, D., and Martin, J. D. 2005. "XANES Investigation of Phosphate Sorption in Single and Binary Systems of Iron and Aluminum Oxide Minerals.” Environmental Science and Technology 39: 2152-60.

[29] Helyar, K. R., Munns, D. N., and Burau, R. G. 1976. "Adsorption of Phosphate by Gibbsite. I. Effects of Neutral Chloride Salts of Calcium, Magnesium, Sodium, and Potassium.” Journal of Soil Science 27: 307-14.

[30] Sillén, L. G., and Martell, A. E. 1970. Stability Constants of Metal-Ion Complexes. London, the Chemical Society 1964, and Supplement No. 1. 